\title{
A Study on the Experience of Studying Literary Therapy in Middle-aged Married Women \\ - Based on Michel Foucault's Self-care(epimeleia heautou) Theory
}

\author{
Sungok Jeong ${ }^{1}$, Yonsuk Chae ${ }^{2}$ \\ ${ }^{1}$ Lecturer, 38453 Dept. Seong-San Liberal Arts Colleage, Daegu Univ., Daegudae-ro 201, Jilly \\ ang-eup, Gyeongsan-si, Gyeongsanbuk-do, Korea, oknie21@hanmail.net \\ ${ }^{2}$ Professor, 41566. Dept. German Teachers College, Kyungpook National Univ., Daehakro 80, \\ Buk-gu, Daegu, Korea, chaeys@knu.ac.kr
}

Corresponding author: Yonsuk Chae

\begin{abstract}
The purpose of this study is to apply the experience of studying literacy therapy to the practical context of Michel Foucault's Self-care theory, thereby understanding the research participants intensively.The research was conducted with six participants, therefore having a limitation on generalizing findings. Also, experience of studying literary therapy was analyzed centering on the texts at the literary-therapy workshop, not on exploring the whole process of the certificate for literary psychology counselor. Hence, follow-up research would be necessary to examine in terms of literary psychology counselors who study it as a non-academic degree course. The course is considered to mean 'a deeper study' in which this process makes middle-aged married women available for new selfdiscovery or leisurely life according to getting older beyond the orientation of employment or careerseeking. As for self-awareness in sequence, the self-discovery and self-awareness were ever expressed together without a big distinction. But some of participants intended to realize clearly or remove the desire of other person or the outside world. Successively, inspecting the self-discipline part, the participants came to know how precious they are such as the necessity for time of being absorbed in themselves, what takes care of themselves, and the consideration on themselves. Finally, checking the self-practice part, the research participants showed the image of strengthening their will to practice themselves even if the previous attempt is frustrated with knowing what is necessary for themselves now. Given arranging, the middle-aged married women, who study the qualification-certificate process for a literary psychology counselor, presented the image of proceeding with securing identity from the viewpoint of self-discovery \& awareness, self-training \& practice through the experience of studying literary therapy. This proves that the experience of studying literary therapy may be helpful for self-care that Michel Foucault says.
\end{abstract}

Keywords: Literary Therapy, Middle-aged Married Women, Self-care(epimeleia heautou) Theory, Michel Foucault

\section{Introduction}

In the report on 'How's Life? 2020' that OECD announced on March 9, the quality of life in South

Received:August 15, 2020; $1^{\text {st }}$ Review Result: September 29, 2020; $2^{\text {nd }}$ Review Result: November 16, 2020 Accepted: December 28, 2020 
Korea still remained at the bottom of the list[1]. Of course, the index for South Korea has improved more than before. Nevertheless, the subjective life satisfaction, with quality of life, was at a very low level. Also, the intensification in a lifelong education system aiming to cope flexibly with the rapid demands and changes of the times led to more people to study in middle age. Thus, according to the announcement of Worknet(2015), 79.3\% of counselors involved women. 34.7\% of them appeared to be in their 40s. Hence, middle-aged female counselors showed the largest ratio among the rest[2]. If so, what will be there motivation in making a difficult decision to learn counseling or psychotherapy in midlife like this? Due to the recent rise in average life expectancy, the age in which people become middle aged can be considered to have changed. Middle aged life is being generally regarded as 30 years old $\sim 65$ years old[3].

Carl Gustav Jung, a Swiss psychiatrist and founder of analytical psychology, first became interested in middle-aged life, using the term "The second half of life." Jung emphasized that" if one was absorbed in success and achievement while adapting to the outside world in the first half of one's life, one should shift toward balance and harmony by thinking about one's own inner desires and meaning of life in the second half of one's life, namely the middle age'. Middle age: experiencing great physical and mental changes in life, can be seen as a crisis of life, but it may be a time to stop for a while, take care of oneself, focus on oneself, and redefine the meaning of life. In this sense, middle-aged married women's study experience in literary therapy is also a useful experience in terms of personal life development before the demands of the times, which require counselors or psychotherapists.

Originally its starting point is literary therapy (Poesie- und Bibliotherapie), which is based on humanities.This is a branch of expression art therapy that utilizes literary media such as prose, poetry, drama and film to help participants solve psychological difficulties through literary activities, such as reading and writing. The ultimate purpose of literary therapy is to help people suffering from mental wounds or unknown psychological pain discover their own unique language through literary activities such as reading and writing [4].

In this context, the role of a literary therapist (literary psychology counselor) is to help participants digest pent-up emotions and form genuine solidarity with therapists to find the language contained inside the participants' minds while selecting literary media and conducting programs in the case of group literary therapy. Literary therapists also help participants' cognitive insights and participants themselves to self-interpret their texts. To do so, literary therapists need, among other things, skills such as language sense, body and mind integration, flexible posture in text interpretation, and meta-reflection capabilities [5].

For that reason, the participants in this study directly experienced literary therapy by becoming a participant at a workshop after receiving the literary-theory education. In this process, as a participant before a literary therapist, they experience literary therapy, entirely face themselves, recognize and come to find their own language.

In this series of experiences, the study focused on the theory of Self-care(epimeleia heautou) by French thinker Foucault. Foucault proposed 'Self-care' as a method of recovery as modern people lost original self in the neoliberal system, which advocates globalization and incites infinite competition. Self-care is 'the consideration on oneself, the act of taking care of oneself, and the behavior of being absorbed in oneself"[6]. According to Foucault, what Self-care emphasizes is to make it available for minimizing the control of power through an individual's giving own law and rule, operating skill, own ethics and self-practice, and to form self-transformation with training and practice. At this time, power implies the one as a frame that functions in our society, thereby suggesting a symbol or a discourse that an individual naturally has.

Foucault stressed the writing training that forms oneself with a method of practicing self-care. $\mathrm{He}$ mentioned that writing is linked to own self and that the subject or object of writing is oneself. This is because of identifying oneself with own cause. Especially, the behavior of reading again what was 
written by oneself was mentioned to be physical training that the main agent personalizes truth and logos. This is also the point where literary therapy meets with self-care because in the course of literary therapy, participants read their own written text and primarily by considering their own inner thoughts, and secondly, by placing a proper distance between the contents described in the text, namely, the consideration of the inner parts of the participants in the text.

The current status of domestic research in literary therapy has been conducted in various fields since 2004, including case studies, program effectiveness verification, program development and application, text development, trends in literary therapy research, and the status of literary therapy majors in the degree process, and the subjects of study vary from youth to adults, infants to senior citizens[7]. However, research on literary therapists or experience in studying literary therapy islimited.

A domestic study that incorporated Foucault's Self-care into counseling, education and psychology at a theoretical level has recently begun to appear. Studies have shown that Self-care(epimeleia heautou) in the fields of ethics education, moral education, philosophy counseling, and scenario therapy is introduced as a way of ethical practice, or self-discipline, and as a way to change the attitude of life[8].

In this study, we would like to understand more deeply based on the text and interview materials the participants wrote during a total of five literary therapy workshops on how middle-aged married women experienced themselves while studying literary therapy. In the presentations, the researcher aims to address how the participants who received the re-education of literary therapy at a new workshop are experiencing such a process.

A further objective of this study is to apply Foucault's Self-care(epimeleia heautou) theory to the experiences of the five participants. Foucault proposed 'Self-care' as a method of recovering this with considering that modern people lost original self in the neoliberal system, which advocates globalization and incites infinite competition. Accordingly, this study is aimed to clearly understand with which process the middle-aged married women's experiences are seen from studying literary therapy becomes the self-care experience based on their written texts and interview materials during five literary therapy workshops.

\section{Research Method and Procedure}

\subsection{Research}

This study was carried out focusing on six people who participated in the qualification process to become a registered certificated literary therapist. The theoretical process in the curriculum, which was continued from March 2018 to February 2020, was made mainly through lectures. This study also contains analysis of focusing on the written text, feedback and sharing at a literary therapy in five workshops in which the research participants experienced as a participant, not as a therapist, and on the one-on-one interview materials of having been conducted after finishing the last workshop. As an open group type, the literary therapy workshops were developed five times for 15 hours with one night and two days each time. One-to-one interviews were conducted once for 90 minutes $\sim 120$ minutes in the semi-structured form to discuss ideas and emotion that the participants experienced in the literarytherapy studying process and at the workshop.

After receiving consent on recording from participants, a transcript was made for feedback and sharing during the literary-therapy workshop, and one-to-one interview. The analysis was made from the perspective of Foucault's Self-care theory focusing these contents and on the texts written by participants. After carrying out the analytical work, the contents were delivered to the participants and asked for feedback.

Foucault proposed with the aim of self-care. First, Self-care needs to be the process-based attitude that practices daily. Second, self-care is a form of turning the eyes to oneself. It implies the gaze at the 
outside, other people and the world to own inner self, namely, the return to oneself. Third, self-care corresponds to multiple acts towards oneself. According to Foucault, these actions allow a human being to transform, purify and change oneself.

For this self-care, self-perception(Connaissance de soi) is needed. Such self-awareness is available through self-care. Foucault accentuated an effort to make the subject's life into a unique work of art through self-care, which is the process of striving for self-transformation based on continuous training and practice without which the self-awareness stops in 'who I am.' According to Foucault, the objective of self-care is not to reach a certain state, but to continue training with waking up every second.

In this way, summarizing based on the objective and the practice skill of self-care that Foucault proposed, they are as follows. First, the main agent perceives subordinate subjectivity. Second, the symbols planted by others or by the outside world are inspected to be removed. Third, training is done by finding the act of looking after the subject amidst livelihood as well as spirit, and within a relationship with others. Fourth, the subject continues to practice with building own worthy life.

Therefore, this study analyzed the participants' texts based on Foucault's self-care process without using a quantitative measurement tool, in order to vividly understand the research participants' experience of studying literary therapy. Hence, the method and the procedure of this study correspond to what was described with the researcher's subjective observation and analysis as for a minority of the middle-aged married women. Thus, as mentioned earlier it would be unable to generalize conclusions. Nevertheless, it is considered to be useful data for the middle aged married women who try to newly start something.

\subsection{Research Participants}

Research participants were six middle-aged married women who studied the qualification process to become a literary therapist between March 2018 to February 2020. Research participants'details are as follows [Table 1].

[Table 1] Research Participants

\begin{tabular}{|c|c|c|c|c|c|}
\hline Name & Age & Gender & Religion & Marriage duration & Children \\
\hline Participant 1 & $60 \mathrm{~s}$ & Female & Christianity & 35 years & 1 son and 1 daughter \\
\hline Participant 2 & $50 \mathrm{~s}$ & Female & None & 32 years & 1 son and 1 daughter \\
\hline Participant 3 & $40 \mathrm{~s}$ & Female & Buddhism & 13 years & 2 sons \\
\hline Participant 4 & $40 \mathrm{~s}$ & Female & Buddhism & 25 years & 2 daughters \\
\hline Participant 5 & $40 \mathrm{~s}$ & Female & Buddhism & 21 years & 2 daughters \\
\hline Participant 6 & $40 \mathrm{~s}$ & Female & None & 18 years & \\
\hline
\end{tabular}

\subsection{Research Contents: Literary Therapy Workshop (1st session 5th session)}

The qualification-certificate process for literary therapist(literary psychology counselor) consisted of initial training(theory) and workshop, clinical training followed by peer practice, and relevant education. This in accordance with the certificate regulation by the Korean Association for Integrative Poetry \&Bibliotherapy[9]. This study was examined focusing on the literary therapy workshop that the research participants directly experienced literary therapy as a participant. The literary therapy workshop consisted 
of a total of five instructional units. The composition by each instructional unit was made of 5 sessions by the tetra system of literary therapy. Each session comprised of Initial phase-Action phase-Integration phase-Reorientation phase in line with the tetra system, with each being developed for three hours each. This study made a suggestion focusing on a writing-related theme based on a session from literary therapy programs [Table 2].

[Table 2] Research Contents: Literary Therapy Workshop

\begin{tabular}{|c|c|c|c|}
\hline session & Topic & Research Purpose & Program Course and Procedures \\
\hline \multirow{5}{*}{1} & \multirow{5}{*}{$\begin{array}{l}\text { Self-discovery } \\
\text { : I support } \\
\text { myself. } \\
2018 \text { Summer }\end{array}$} & $\begin{array}{l}\text { Initial phase : } \\
\text { Introduce myself to } \\
\text { the present }\end{array}$ & $\begin{array}{l}\text { Orientation, Alienization } \\
\text { To express myself in six sentences (starting with 'I'm standing on the } \\
\text { road') }\end{array}$ \\
\hline & & $\begin{array}{l}\text { Action phase : } \\
\text { To perceive me as a } \\
\text { subordinate }\end{array}$ & $\begin{array}{l}10 \text { words that come to mind when I think of my interpersonal } \\
\text { relationship } \\
\text { Writing fairy tales with } 10 \text { words, writing letters to the main character }\end{array}$ \\
\hline & & $\begin{array}{l}\text { Action phase : } \\
\text { To perceive me as a } \\
\text { subordinate }\end{array}$ & $\begin{array}{l}\text { Write } 10 \text { sentences of 'I have to do' } \\
\text { Feel free to write after writing }\end{array}$ \\
\hline & & $\begin{array}{l}\text { Integration phase : } \\
\text { To conceal oneself }\end{array}$ & $\begin{array}{l}\text { Writing using } 10 \text { words that I like } \\
\text { Chevena Writing }\end{array}$ \\
\hline & & $\begin{array}{l}\text { Reorientation phase : } \\
\text { To return to oneself }\end{array}$ & $\begin{array}{l}\text { To express myself in six sentences } \\
\text { Compare to first session, write to yourself }\end{array}$ \\
\hline \multirow{5}{*}{2} & \multirow{5}{*}{$\begin{array}{l}\text { Self-discovery } \\
\text { and } \\
\text { Self-awareness } \\
\\
\text { : You can take a } \\
\text { break. } \\
2018 \text { Winter }\end{array}$} & $\begin{array}{l}\text { Initial phase : } \\
\text { Freely }\end{array}$ & $\begin{array}{l}\text { To scribble while listening to music } \\
\text { Choose a partner and write a letter }\end{array}$ \\
\hline & & $\begin{array}{l}\text { Action phase : } \\
\text { To perceive one's own } \\
\text { desires/feeling }\end{array}$ & $\begin{array}{l}\text { Practice noticing (desire and emotion) - Now I notice } \\
\text { Feel free to write now }\end{array}$ \\
\hline & & $\begin{array}{l}\text { Action phase : } \\
\text { self-awareness }\end{array}$ & $\begin{array}{l}\text { Taking a picture of each other's backs (in pairs) } \\
\text { Writing a Conversation with the Back }\end{array}$ \\
\hline & & $\begin{array}{l}\text { Integration phase : } \\
\text { To conceal oneself }\end{array}$ & $\begin{array}{l}\text { Choose a question from Neruda's 'Book of Questions' } \\
\text { My life as a question }\end{array}$ \\
\hline & & $\begin{array}{l}\text { Reorientation phase : } \\
\text { To return to oneself }\end{array}$ & $\begin{array}{l}\text { Free writing after meditation } \\
\text { Writing a letter to a companion }\end{array}$ \\
\hline \multirow{5}{*}{3} & \multirow{5}{*}{$\begin{array}{l}\text { Self-awareness } \\
\text { : My life story } \\
2019 \text { Summer }\end{array}$} & $\begin{array}{l}\text { Initial phase : } \\
\text { Introduce myself to } \\
\text { the present }\end{array}$ & $\begin{array}{l}\text { express current mood in pixel coloring } \\
\text { Blind contour drawing, Free writing after drawing }\end{array}$ \\
\hline & & $\begin{array}{l}\text { Action phase : } \\
\text { Find Yourself }\end{array}$ & $\begin{array}{l}\text { Panorama of the body - childhood, school, adult } \\
\text { Choose one memorable story and write it specifically }\end{array}$ \\
\hline & & $\begin{array}{l}\text { Action phase : } \\
\text { Find Yourself }\end{array}$ & $\begin{array}{l}\text { Panorama of Life - Five Important Stories of My Life } \\
\text { Choose one memorable story and write it specifically }\end{array}$ \\
\hline & & $\begin{array}{l}\text { Integration phase : } \\
\text { To conceal oneself }\end{array}$ & $\begin{array}{l}\text { Read picture book 'I Want to See a Whale' } \\
\text { My Whale's Story Free Writing }\end{array}$ \\
\hline & & $\begin{array}{l}\text { Reorientation phase : } \\
\text { To return to oneself }\end{array}$ & $\begin{array}{l}\text { Listen to Oh Eun's poem 'I Am Today' and write when imitating } \\
\text { Writing a letter to Today's Me }\end{array}$ \\
\hline 4 & $\begin{array}{l}\text { Self-training } \\
\text { : I am traveling }\end{array}$ & $\begin{array}{l}\text { Initial phase : } \\
\text { Introduce myself to } \\
\text { the present }\end{array}$ & $\begin{array}{l}\text { Gift me the language I need now } \\
\text { To express life in comparison to travel (metaphors) }\end{array}$ \\
\hline
\end{tabular}




\begin{tabular}{|c|c|c|c|}
\hline & \multirow[t]{4}{*}{$\begin{array}{l}\text { now } \\
\text { Winter of } 2019\end{array}$} & $\begin{array}{l}\text { Action phase : } \\
\text { self-care }\end{array}$ & $\begin{array}{l}\text { Drawing life trees (root/stem/plant) } \\
\text { Writing about what you need, what you want to give to the tree of life }\end{array}$ \\
\hline & & $\begin{array}{l}\text { Action phase : } \\
\text { self-care }\end{array}$ & $\begin{array}{l}\text { Drawing a scene that comes to mind after hearing Kwon Dae-woong's } \\
\text { poem, } \\
\text { free verse }\end{array}$ \\
\hline & & $\begin{array}{l}\text { Integration phase : } \\
\text { Become friends with } \\
\text { yourself }\end{array}$ & $\begin{array}{l}\text { The Night Story of the Tree of Life } \\
\text { Writing a Conversation with the Tree of Life }\end{array}$ \\
\hline & & $\begin{array}{l}\text { Reorientation phase : } \\
\text { To return to oneself }\end{array}$ & $\begin{array}{l}\text { Free writing after a morning walk that no one passes by } \\
\text { Listen to Park No-hae's poem, "When you go on a trip, leave alone" }\end{array}$ \\
\hline \multirow{5}{*}{5} & \multirow{5}{*}{$\begin{array}{l}\text { Self-training } \\
\text { and Self-practice } \\
\text { : Warm exterior } \\
\text { of the Winter } \\
\text { forest } \\
\text { Early Spring } \\
2020\end{array}$} & $\begin{array}{l}\text { Initial phase : } \\
\text { Take care of yourself }\end{array}$ & $\begin{array}{l}\text { To recognize feelings when you are alone } \\
\text { What you want to tell me now }\end{array}$ \\
\hline & & $\begin{array}{l}\text { Action phase : } \\
\text { Take care of yourself }\end{array}$ & $\begin{array}{l}\text { Draw the mask I want to wear } \\
\text { On a day you want to wear a mask, imagine writing }\end{array}$ \\
\hline & & $\begin{array}{l}\text { Action phase : } \\
\text { Take care of yourself }\end{array}$ & $\begin{array}{l}\text { Invite languages (poetry, phrases) into the treasure trove } \\
\text { Write down the language you want to fill in the treasure complex. }\end{array}$ \\
\hline & & $\begin{array}{l}\text { Integration phase : } \\
\text { To find one's own } \\
\text { pleasure }\end{array}$ & $\begin{array}{l}\text { Invite Dinner (Who wants to invite, reason for invitation) } \\
\text { Imagining and writing a letter from an invitee }\end{array}$ \\
\hline & & $\begin{array}{l}\text { Reorientation phase : } \\
\text { To return to oneself }\end{array}$ & $\begin{array}{l}\text { Narrative Gallery - My story is a gallery. } \\
\text { Writing to describe my image }\end{array}$ \\
\hline
\end{tabular}

\section{Findings and Discussion}

\subsection{Findings}

\subsubsection{Self-Discovery: 'This is what I am. I need some warm sunshine'}

In this study, self-discovery can be divided into two parts. First, it is about participants looking back on their lives and finding their own abilities or facts that they did not know. Second, be aware that one's actions or thoughts are centered on others or subjugated by the conventional wisdom of society rather than being self-discovered. The participants' self-discovery continued throughout the workshop. In the Initial phase of the workshop (1st,2nd) there were mainly introspective findings. Participant 1 and Participant 3 were also ambiguous and complex, making it difficult for them to see inside themselves.

I don't want to bother you. / But it's light.

It's okay. I think it expressed me(Session 1, Participant4).

I guess I wasn't doing a good job managing the people around me.

Some people say thank you by reciting it at the end of each year(Session 1, Participant 2).

You were immersed in it without realizing it.

I wanted to make it look cool, but... I'm afraid it's not expressed enough.

You care about your two daughters and husbands./You're leaning to one side(Session 2, participant 6).

One day I felt very complicated in my head.

"Am I doing well?" or "Is something going wrong?" I think.

Everything became meaningless, and only emptiness remained in my heart and tormented me.

I just wanted to rest.

I was walking on a quiet country road, leaving a feeling of discomfort in my heart(Session 1, Participant $3)$. 
[Table 3] Participants' Paintings

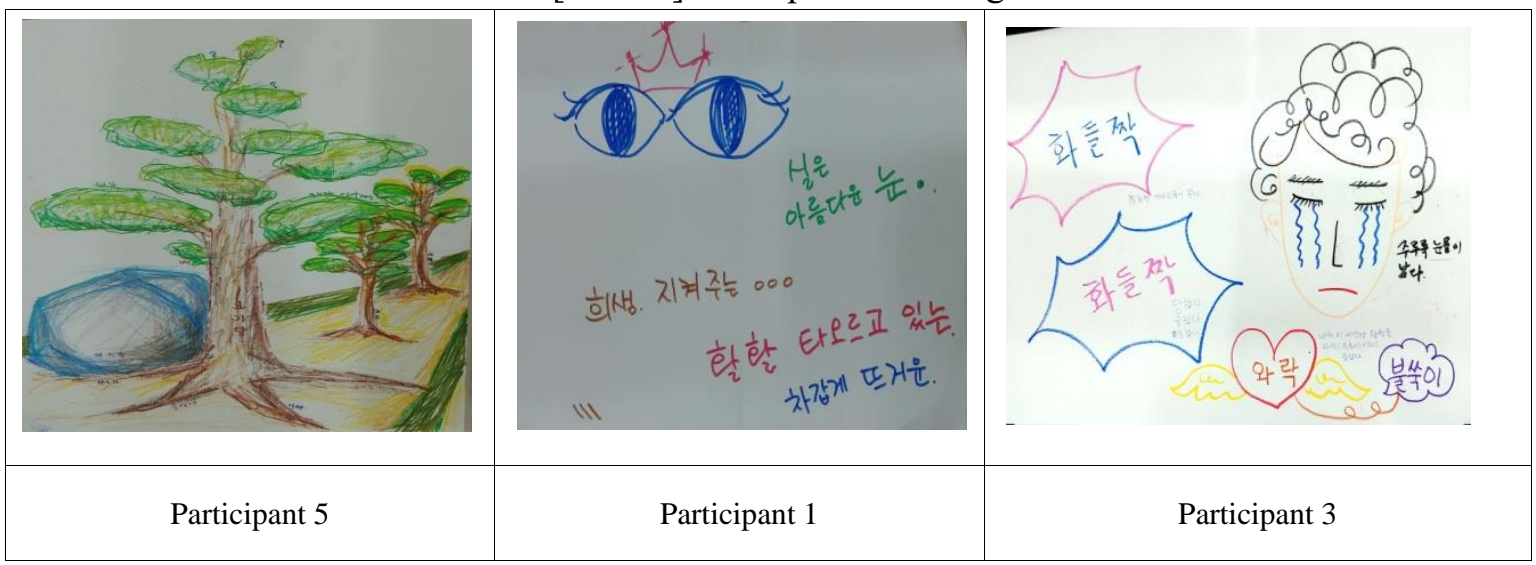

\subsubsection{Self-Awareness: 'I'd like to be a very nice person to me now'}

Foucault regarded Self-care(epimeleia heautou) as the extended concept of including this selfawareness. Thus, it was emphasized that self-awareness is needed for self-care and that such selfperception is available through self-care. This study made an analysis through distinguishing it from self-discovery with the focus on the behavior of intending to remove with which a participant realizes a frame made by others or by the outside world.

In fact, the research participants expressed self-discovery and self-perception together without distinction at the workshop. However, among participants, there was even a case that definitely realizes a desire of others or of the outside world, or that decides on an attempt for removing it. Particularly in the case of the five participants, there were many expressions and complaints of difficulties due to several conflicts(husband's family, children, husband \& wife) in those days rather than self-awareness at the beginning of the workshop. But the interview led to having been told their self-awareness that was made from the first workshop.

But if you've wanted to be a good person to others,

Now I want to be a good person to me (Session2, Participant 1).

It's hard to wrap it with a thread. /packing, exaggeration, hypocrisy, out of the perimeter dam.

I want to be honest(Session1, Participant 2).

I thought I was watering them. /I brought them in.

You've been keeping it/ Now what should I do.

May it be used only to them and repay their love(Session4, Participant5).

[Table 4] Participants' Paintings

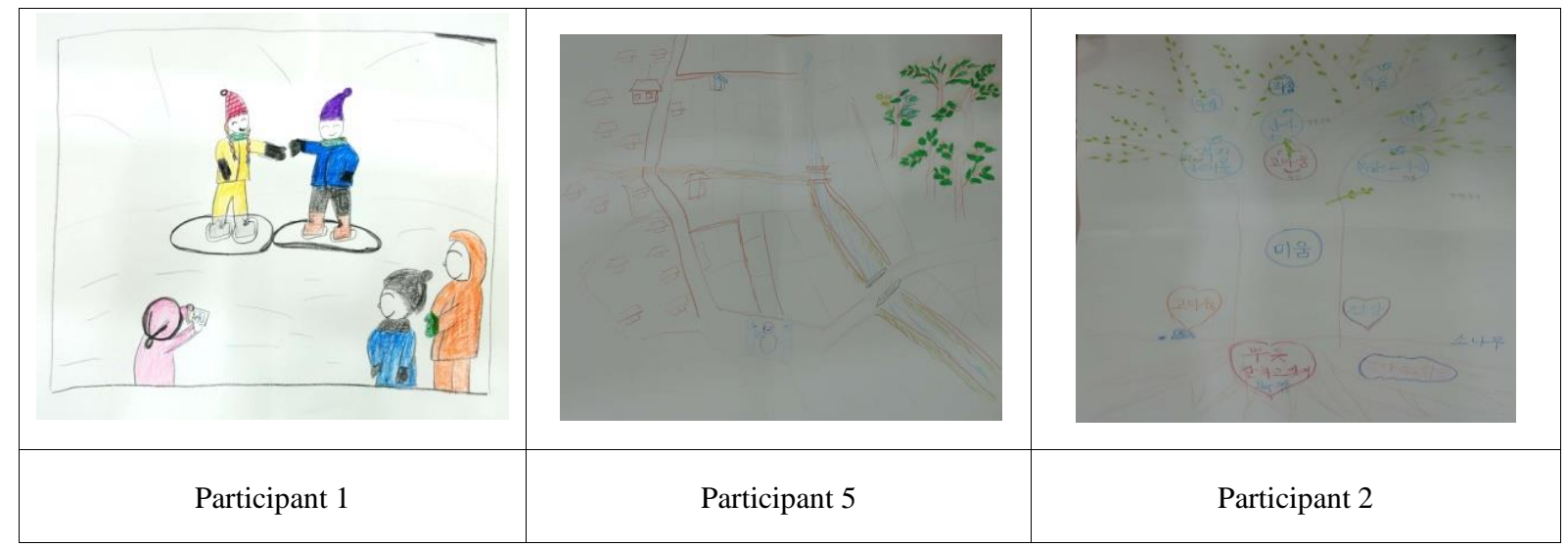




\subsubsection{Self-training: 'My big, nice whale that follows very slowly'}

As the workshop is continued, the participants came to know how precious those things are such as the necessity of time that is immersed in themselves, as what takes care of oneself, and as what is considerate of oneself. The participants got around to being capable of waiting and taking care of oneself, as my big, nice whale that follows very slowly,' which 'slips out of an egg' and 'tries to waddle along.' It is what now trains the act of caring for the subject in life and inside a relationship with others.

There's something in me/ There must be something in the egg.

Cold and hard / precious / what I want / eggs.. Get out of here.

Break it. Break it! It explodes(Session 4, Participant 4).

Now she knows how to look at the night sky with her chin on her chin. No, I already knew.

Now, in reality, the big lump standing around tries to move little by little with a smile.

I'm just trying to smile and move forward little by little. There is already a way.

I'm going to stop looking back and waddle along.

When I ask him to hold hands, he grabs me and tries to do it' / She's leaving now(Session5, Participant $5)$.

[Table 5] Participants' Paintings

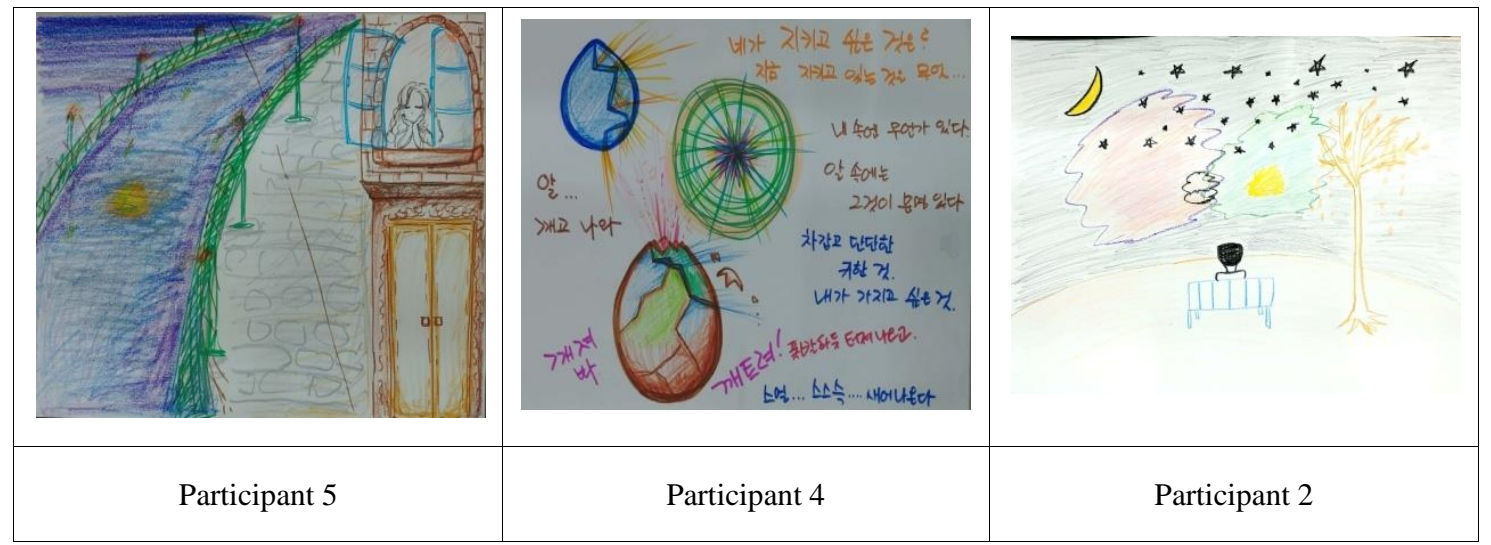

\subsubsection{Self-Practice: 'ME(s) with a repeat of being one and being two, touching'}

The objective of self-care is not to reach a certain state. It is what proceeds with forming selftransformation through going on training and practicing in own life. Ultimately, self-care is the process of continuing to practice for forming the main agent oneself through which the subject adds intrinsic order to own life.

Another me, walking hand in hand./ It's touching to see people repeating "one and two."

(Feels like I've been given something I didn't even think of.)/This workshop feels special. Light. Fresh. It used to be very heavy in the past, but now it feels like it's shaking.

It was time to think a lot again. "Mom and I" live differently, but our minds are similar. I regret not expressing it. It makes me promise to express it before it's too late. Are you going to be a little chatty now? It's homework. 'Expression'(Session4, participant 6).

In particular, he spent another year swallowing blood tears. He continues to comfort himself and courageously advance the will of education, which has collapsed his self-esteem and self-confidence. Many times when I talked to myself, noticed my feelings, and thought about what a true adult should do. days of indissoluble human relations Despite many worries and conflicts, he tries to find gratitude. To me, tears are reflection and healing(Session4, Participant 1). 
[Table 6] Participants' Paintings

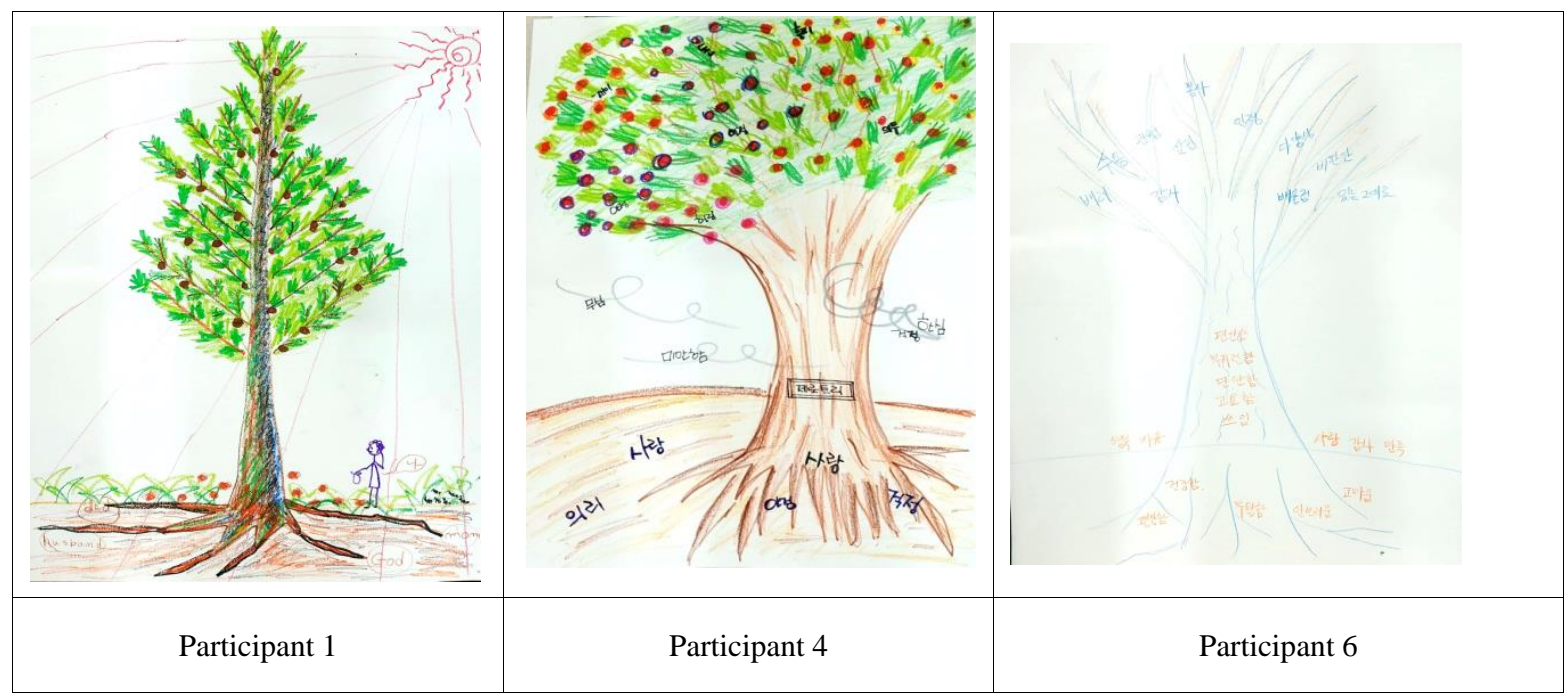

\subsubsection{Self-Care: my constantly changing and evolving self, and my different inner self.}

In this process, participants evaluated their ability to continuously pursue self-development and selfchange being the most important results. First of all, I could feel significant changes and improvements in myself. The most noticeable change for participants is not to accept and conform to reality as it is, but to become the main body of life on its own, caring for and preparing itself. This is the most precious achievement they have made in the process. This is because the process of self-discipline is both an achievement and a meaning.

\subsection{Discussion}

This study explored through which process their experience of studying literary therapy came to cause self-care targeting six middle-aged married women who took part in the qualification process to become a privately registered certified literary therapist. Examining self-discovery, there were primarily many introspective discoveries at the beginning of the workshop. There was also a participant who found it difficult to look into her own inner self deeply and effectively. However, the continuation of the workshop led to him knowing what is necessary oneself with the focus on own image, or even distinguishing what makes oneself difficult from own experience. The analysis was made by taking Foucault's self-care(epimeleia heautou) as the rationale focusing especially on the texts that the research participants wrote when experiencing the literary-therapy workshop, on feedback \& sharing, and on the one-on-one interview, which was conducted after finishing the workshop. At this time, the skill of practicing self-care(epimeleia heautou) was divided into self-discovery, self-awareness, self-training and self-practice.

Therefore, we would like to present the implications of the major research results, compare them with previous research, and deepen the discussion. First of all, looking at self-discovery, there were many introspective findings in the early days of the workshop, and there were also participants who could not see inside themselves indeeply. However, as the workshop continued, they focused on their appearance and knew what they needed, or they recognized what made them suffer from their own experiences. Throughout the workshop, one can see that one's ability to look into one's inner self improves and one's desire becomes clear. In the study of growth and change experience, Choi Sun-ae and Han Sook-ja's post-middle-aged married women who chose the life of counselors were also aware of their feelings and desires, and reported positive changes in their perception of themselves and attitudes toward life. This is consistent with the results of this study. 
Next, self-awareness was expressed together without much distinction between self-discovery and selfawareness, but among the participants, they wanted to recognize or eliminate the needs of others or the outside world. This is supported byJung Sung-ok's study on literary therapy's writing for college students that suggested to help the participants recognize who they are by expressing and reinterpreting their stories[10].

Examining the self-training section, participants found out how precious time is to them to devote themselves, to care for themselves, and to be considerate of themselves. Even though they changed slowly, they waited even if they were afraid of the problems of reality, and they were determined to move on. Rather than following the conventional wisdom of the existing society, the focus is on their own speed and processing methods.

Finally, checking the self-practice part, the research participants showed the image of strengthening their will toimprove themselves even if the previous attempt is frustrated with knowing what is necessary for themselves now. They provide themselves tasks and encourage themselves so that they can practice what they pursue even if it is challenging. The constant practice of this free will can be seen as gradually securing self-reliance from repressed symbols, as stated by Foucault.

To conclude, middle-aged married women who study the course of the Literary Psychological Counselor's Certificate were shown to secure their identity from the perspective of self-discovery, recognition, self-discipline and practice through their experience in literary therapy. This can be seen assupporting Foucault's Self-care (epimeleia heautou) experience in literary therapy. This study analyzed the texts applying the experience of studying literary therapy to the practical context in Foucault's Self-care theory, thereby having intended to understand the research participants more dimensionally. Due to the study being only six research participants involved the findings can be only be limited in their findings. Also, the experience of studying literary therapy was analyzed centering on the texts at the literary-therapy workshop, not on exploring the whole process of the certificate for literary psychology counselor. Hence, follow-up research seems to be necessary with literary psychology counselors who study it as a non-academic degree course. This is considered to mean 'a deeper study' in which this process makes middle-aged married women available for new self-discovery or leisurely life according to growing old beyond the orientation of employment or career-seeking[11].

\section{References}

[1] Heasik Jung, Seungah Kim, Quality of Life in Korea on OECD Better Life Index, International Health and Welfare Policy Trends 1, OECD, How's Life? 2020: Measuring Well-being - Highlights, March, (2020)

[2] 2015 Korea Vocational Outlook, Korea Employment Information Service, (2014)

[3] Sunae Choi, Sukja Han, An Interpretative Phenomenological Analysis of Change and Growth in Middle-aged Married Women s Life Who Chose to Become Counselors, The Kokea Journal of East West Mind Science, (2019), Vol.22, No.1, pp.35-54.

[4] Yonsuk Chae, A Series of Integrative Poetry \& Bibliotherapy, kyoyookbook, (2015)

[5] Yonsuk Chae, Seongbeom Kim, Yeongok Kim, Hyegyeong Kim, Deukja Moon, Yeongui Bae, Jihyeon Sim, Eunjeong Yoon, Seongok Jung, Yeongmi Cho, Iok Han, Supervision in the Poesie- and Bibliotherapy, kyoyookbook, (2020)

[6] Foucault, MThe Hermeneutics of the Subject (Translated by Se Kwang Shim), dongmunseon, (2007)

[7] Seon Ah Heo, Analysis of Research Trends in Literatry Therapy- Focused on Domestic Dissertations (2004-2014), Department of Literatry Therapy Graduate School Kyungpook National University, Doctoral Dissertation, (2016)

[8] Soo Jin Park, Development and Effects of Scenario Therapy Program based on Foucault's Care of the self Theory, Department of Education Graduate School Kyungsung University, Doctoral Dissertation, (2018) 
[9] Heeju Cho, The positive Signature Through Literary Treatment. Kyoyookbook, (2020)

[10] Sung Ok Jeong, The Writings in Literatherapy and the Narrative Inquiry of Relational Ego Identity, Department of Literatherapy Graduate School Kyungpook National University, Doctoral Dissertation, (2017)

[11] Masaya Chiba, The discovery of study (Translated by Jee Park), Chaeksesang,(2019) 